\title{
Canopy spectra of giant reed and associated vegetation
}

\author{
J.H. EVERITT, C. YANG, M.A. ALANIZ, M.R. DAVIS, F.L. NIBLING, AND C.J. DELOACH
}

Authors are Range Scientist, Agricultural Engineer, Biological Technician, and Pilot, USDA-ARS, 24I3 E. Highway 83, Weslaco, Tex. 78596; Botanist, U. S. Bureau of Reclamation, P. O. Box 25007 (D-8220), Denver, Colo. 80225-0007; Research Entomologist, USDA-ARS, 808 E. Blackland Rd., Temple, Tex. 76502.

\section{Abstract}

This paper describes the spectral light reflectance characteristics of giant reed (Arundo donax $\mathbf{L}$.) and the application of aerial color-infrared photography and videography for distinguishing infestations of this invasive plant species in Texas riparian areas. Airborne videography was integrated with global positioning system (GPS) and geographic information system (GIS) technologies for mapping the distribution of giant reed. Field spectral measurements showed that giant reed had higher near-infrared reflectance than associated plant species in summer and fall. Giant reed had a conspicuous pink image response on the colorinfrared photography and videography. This allowed infestations to be quantified using computer analysis of the photographic and videographic images. Accuracy assessments performed on the classified images had user's and producer's accuracies for giant reed that ranged from $78 \%$ to $100 \%$. Integration of the GPS with the video imagery permitted latitude-longitude coordinates of giant reed infestations to be recorded on each image. A long stretch of the Rio Grande in southwest and west Texas was flown with the photographic and video systems to detect giant reed infestations. The GPS coordinates on the color-infrared video scenes depicting giant reed infestations were entered into a GIS to map the distribution of this invasive weed along the Rio Grande.

Key Words: light reflectance, color-infrared photography, colorinfrared videography, image analysis, accuracy assessment, Arundo donax, global positioning system, geographic information system

Giant reed (Arundo donax L.) is a robust perennial grass 2 to 8 $\mathrm{m}$ tall growing in many-stemmed cane-like clumps. The fleshy, creeping rootstocks form compact masses from which arise tough fibrous roots that penetrate deeply into the soil (Perdue 1958, Dudley 2000). It spreads vegetatively by either rhizomes or plant fragments.

Giant reed is native to India, but has been widely introduced as an ornamental and for bank stabilization. Subsequently, it has become naturalized and invasive in many tropical, subtropical, and warm-temperate regions of the world (Dudley 2000). It grows on a variety of soil types from loose sands and gravelly soils to heavy clays and river sediments. Optimum growth occurs in well drained soil with ample moisture, from freshwater to semi-saline soils at margins of brackish estuaries (Perdue 1958, Dudley 2000).

\footnotetext{
The authors thank A. Gomez and J. Forward for their assistance in collecting GPS data and I. Cavazos for his image processing work.

Manuscript accepted 13 May 04.
}

\section{Resumen}

Este artículo describe las características de reflectancia espectral de la luz del "Giant reed" (Arundo donax L.) y la aplicación de la fotografía aérea de color-infrarroja y la videografía para distinguir infestaciones de esta especie vegetal invasora de las áreas ribereñas de Texas. La videografia aérea se integró con tecnologías de sistemas de posicionamiento global (GPS) y sistemas de información geográfica (GIS) para mapear la distribución del "Giant reed". Mediciones espectrales de campo mostraron que el "Giant reed" tiene una mayor reflectancia de infrarroja- cercana que las plantas asociadas en verano y otoño. El "Giant reed" tuvo una imagen conspicuamente rosa en la fotografía de color-infrarroja y la videografia. Esto permitió cuantificar las infestaciones utilizando análisis por computadora de las imágenes de fotografía y videográficas. Evaluaciones de certeza realizadas en las imágenes clasificadas produjeron certezas del usuario y productor para el "Giant reed" que variaron del 78 al $\mathbf{1 0 0 \%}$.La integración de GPS con las imágenes de video permitió registrar en cada imagen las coordenadas de latitud-longitud de las infestaciones del "Giant reed". Una larga extensión del Río Grande en el suroeste y oeste de Texas fue sobrevolada con sistemas de fotografía y video para detectar infestaciones de "Giant reed". Las coordenadas de GPS en las escenas de color-infrarrojo representando las infestaciones de "Giant reed" fueron introducidas al sistema de información geográfica (GIS) para mapear la distribución de esta maleza invasora a lo largo del Río Grande.

In addition to being used horticulturally and for erosion control, giant reed has played an important role in the development of music. The cane is the primary source of reeds for woodwind instruments (Perdue 1958) and commercial plantations of giant reed exist for musical instrument production (Dudley 2000). Giant reed has been used in light construction for plaster backing, concrete reinforcement, and thatch. The split stems have been woven into mats, baskets, pens, cages, fish traps, and furniture seats. It is also a source of cellulose for rayon and paper pulp. The young stems and leaves are eaten by all livestock, including pigs and poultry (Cheatham and Johnston 1995).

Giant reed was introduced into the United States in California in the early 1800's and quickly became naturalized. It is now found throughout the southern half of the United States from Maryland to California, but is most invasive along muddy banks of creeks and rivers in the southwestern United States, with the densest stands growing along coastal rivers of southern California and along the Rio Grande in west and southwest Texas (Dudley and Collins 1995, Bell 1997, Tracy and Deloach 1998). Giant reed is a severe threat to riparian areas where it displaces native plants and animals by forming massive stands that pose a wildfire 
threat (Frandsen and Jackson 1994). It also alters channel morphology by retaining sediments and constricting flows and may reduce stream navigability (Dudley 2000). It consumes excessive amounts of water, as much as 2,000 liters $\mathrm{m}^{-1}$ of standing plant to supply its incredible rate of growth. Under optimum conditions it can grow more than $5 \mathrm{~cm}$ per day (Perdue 1958, Bell 1997).

Several control methods have been employed on giant reed. Mechanical eradication with backhoe has been ineffective because the rhizomes buried under the soil will readily resprout. Prescribed burning has not been successful because it cannot kill the rhizomes and generally promotes giant reed regeneration over native riparian species (Dudley 2000). Biological control with insects may have potential, since several insects are known to feed on it in Eurasia and Africa; however, none of these have been approved by the USDA (Tracy and Deloach 1998). There has been partial success on using cattle, sheep, and goats for control. Glyphoshate [N-(phosphonomethyl) glycine] applied broadcast or as a basal treatment to cut culms has been the most successful control method (Dudley 2000).

Determining the extent of noxious plant infestations in wildland areas is difficult because of the generally great expanse and inaccessibility of these areas. Remote sensing techniques offer rapid acquisition of data with generally short turn-around time at costs lower than ground surveys (Tueller 1982, Everitt et al. 1992). The value of remote sensing techniques for distinguishing some plant species and communities is well established (Tueller 1989, Everitt et al. 1995, Driscol et al. 1997). Field reflectance measurements (Gausman et al. 1977a, Everitt et al. 1987, Lass and Callihan 1997) and aerial photography, airborne electronic imagery (multispectral and hyperspectral), and satellite data have been used to remotely detect invasive weeds and woody plant species (Gausman et al. 1977b, Richardson et al. 1981, Anderson et al. 1993, Everitt et al. 1994, Lass et al. 1996, Lass and Callihan 1997, Parker-Williams and Hunt 2002).

Remotely sensed data have been integrated with geographic information system (GIS) and global positioning system (GPS) technologies for detecting and mapping the distribution of noxious plant species (Dewey et al. 1991, Everitt et al. 1996, Anderson et al. 1996). Remote observations in georeferenced formats help assess the extent of infestations, develop management strategies, and eval- uate control measures on noxious plant populations.

Recently, DiPietro et al. (2002) used AVIRIS hyperspectral imagery and standard imaging spectrometry techniques to detect and map giant reed in riparian areas in southern California. Little information is available on the use of remote sensing techniques to distinguish giant reed infestations in other areas.

The purpose of this study was to determine the feasibility of using remote sensing technology to detect giant reed infestations in riparian areas in Texas. The study objectives were: (1) to establish the plant canopy light reflectance characteristics of giant reed and associated vegetation; (2) to evaluate the use of aerial photography and videography for distinguishing giant reed; and (3) to demonstrate the integration of airborne videography, GPS, and GIS technologies for mapping giant reed distribution.

\section{Methods and Materials}

This study was conducted at several locations in south, southwest, and west Texas. Study sites were located near Weslaco $\left(26^{\circ} 9 \mathrm{~N} 97^{\circ} 59 \mathrm{~W}\right)$, South Padre Island $\left(26^{\circ} 4 \mathrm{~N} 97^{\circ} 9 \mathrm{~W}\right)$, and Goliad $\left(28^{\circ}\right.$ $40 \mathrm{~N} 97^{\circ} 13 \mathrm{~W}$ ) in south Texas. Other study sites included a long stretch of the Rio Grande River from near Laredo $\left(27^{\circ} 15 \mathrm{~N}\right.$ $99^{\circ} 29 \mathrm{~W}$ ) in southwest Texas to Presidio $\left(29^{\circ} 20 \mathrm{~N} 104^{\circ} 3 \mathrm{~W}\right)$ in west Texas. Aerial photography and videography, radiometric reflectance measurements, computer image analysis, and ground truth observations were conducted for this study.

Reflectance measurements were made in the field near Weslaco and South Padre Island. Measurements were made at the Weslaco site at 5 time periods: late August 2000, and mid-May, mid-July, early September, and late October 2001. With the exception of the late October 2001 period, measurements were made at the South Padre Island site during the same time periods. At Weslaco, measurements were made on giant reed, honey mesquite (Prosopis glandulosa Torr.), sandbar willow (Salix exigua Nutt.), sunflower (Helianthus annus L.), bermudagrass [Cynodon dactylon (L.) Pers.], mixed herbaceous species, and bare soil. Sunflower is an annual and consequently, was measured only in May 2001. Measurements were not made on bermudagrass in August 2000 because it was not available in sufficient amounts. At the Port Isabel site, measurements were made only on common reed (Phragmites australis Trin.). Common reed was not measured in late October 2001 because it was not available in sufficient amounts. Honey mesquite, sandbar willow, bermudagrass, common reed, and mixed herbaceous species are common species and mixtures that often grow in association with giant reed.

Reflectance measurements were made on 10 randomly selected canopies of each species or soil surfaces with a Barnes modular multispectral radiometer (Robinson et al. 1979). Measurements were made in the visible green ( 0.52 to $0.60 \mu \mathrm{m})$ visible red $(0.63$ to $0.69 \mu \mathrm{m})$ and near-infrared $(0.76$ to $0.90 \mu \mathrm{m})$ spectral bands with a sensor that had a 15-degree field-of-view placed 1.0 to $1.5 \mathrm{~m}$ above each plant canopy or soil surface. The area within the sensor field-of-view ranged from 0.26 to $0.39 \mathrm{~m}$. Reflectance measurements were made between 1100 and 1500 hours Central Standard Time under sunny conditions. Radiometric measurements were corrected to reflectance using a barium sulfate standard (Richardson 1981). Overhead vertical photographs were obtained of the plant canopies measured with a radiometer to help interpret reflectance data.

Differences among green, red, and nearinfrared reflectance data were tested using analysis of variance. Duncan's multiple range test was used to separate means at the 0.05 probability level (Steel and Torrie 1980).

Color-infrared photography and videography were used for this study. Kodak Aerochrome color-infrared $(0.50$ to 0.90 Fm) type 2443 film was used with a Fairchild type K-37 large format $(23 \mathrm{~cm}$ by $23 \mathrm{~cm}$ ) mapping camera. Colorinfrared film is sensitive in the visible green $(0.50$ to $0.60 \mu \mathrm{m})$, visible red $(0.60$ to $0.75 \mu \mathrm{m})$, and near-infrared $(0.76$ to $0.90 \mu \mathrm{m}$ ) spectral bands. The camera was equipped with a $305 \mathrm{~mm}$ lens with an aperture setting of $\mathrm{fl} 1 \mathrm{at} 1 / 250 \mathrm{sec}$. Aerial videography was taken with a 3-camera multispectral digital video imaging system (Everitt et al. 1995). The system was comprised of 3 charge-coupled device (CCD) aligned cameras, a computer, a color encoder, and super-VHS recorder. The cameras were visible/near-infrared $(0.4$ to 1.1 Fm) light sensitive. Two of the cameras were equipped with visible yellowgreen $(0.555$ to $0.665 \mu \mathrm{m})$ and red $(0.623$ to $0.635 \mu \mathrm{m}$ ) filters, respectively, while the third camera had a near-infrared $(0.845$

\footnotetext{
${ }^{1}$ Trade names are included for the benefit of the reader and do not imply endorsement of or a preference for the producted listed by the USDA.
} 
to $0.857 \mu \mathrm{m}$ ) filter. All the cameras had fixed lenses with $12.5 \mathrm{~mm}$ focal lengths.

The video system computer was a Pentium (100 MHZ) with an image grabbing board (640 × 480 pixel resolution) and a 1000-megabyte hard drive. The near-infrared, red, and yellow-green image signals from the cameras were subjected to the RGB inputs, respectively, of the grabbing board in the computer and also the RGB inputs respectively, of the color encoder. This permits the simultaneous acquisition of both digital and analog realtime color-infrared composite imagery. The digital imagery was stored in the computer hard drive while the analog imagery was recorded on the super-VHS recorder. The hard drive can store 1000 colorinfrared composite images.

Both color-infrared photography and color-infrared composite video imagery were acquired simultaneously of giant reed study sites near Goliad on 17 August 2001 and of a stretch of the Rio Grande from near Laredo to Presidio on 25 June and 26 July 2002. Imagery of the Goliad site was obtained at altitudes ranging from 600 to $900 \mathrm{~m}$ above ground level, while imagery of the Rio Grande was acquired at 3,050 m above ground level. The photographic scales ranged from $1: 2,000$ to $1: 10,000$, whereas the pixel resolution of the video images ranged from 0.7 to $3.3 \mathrm{~m}$.

A Model 404 Cessna airplane, equipped with a camera port in the floor, was used for obtaining the aerial photography and videography. The cameras were maintained in nadir position during image acquisition. All imagery was acquired between 1030 and 1400 hours Central Standard Time under sunny conditions.

Two color-infrared photographs and a color-infrared video image of study sites were subjected to computer classification and accuracy assessment. These included a color-infrared photographic transparency (1:10,000 scale) of a giant reed study site near Del Rio obtained on 25 June 2002 and a color-infrared photographic transparency $(1: 3,000$ scale $)$ and a colorinfrared digital video image $(1.0 \mathrm{~m}$ pixel $)$ taken simultaneously of a giant reed study site near Goliad on 17 August 2001. A Trimble differential GPS Pathfinder Pro XRS system that provided submeter accuracy was used in the field to establish control points on the digitized photographic transparencies of the giant reed study sites. The transparencies were scanned at 600 dots per inch. Erdas Imagine software (Version 8.3) was used to georeference the transparencies (Erdas 1997).

The digital video image of the giant reed site near Goliad was subjected to pixel line correction and image to image registration using Adobe Photoshop and Image Pro software, respectively. For the band to band registration process, the red band was used as the image base to rectify the other 2 bands. The registered colorinfrared composite video image was georeferenced to the color-infrared photographic image of the giant reed site using an image to image procedure in Erdas Imagine (Erdas 1997).

The 3 images were subjected to an Iterative Self Organizing Data Analysis (ISODATA) which performs unsupervised classifications on the basis of specified iterations and recalculates statistics for each iteration (Erdas 1997). The ISODATA technique uses minimum spectral distance to assign a cluster for each selected pixel. It begins with arbitrary cluster means, and each time the clustering repeats, the means of the clusters are shifted. The new cluster means are used for the iteration.

Initially, the unsupervised classification created 32 to 36 classes. Many of the initial classes were combined resulting in 4 or 5 data classes. For both the photographic and video images of the giant reed study site near Goliad, each completed unsupervised classification created 4 data classes. The classes consisted of giant reed, mixed herbaceous vegetation, mixed brush, and soil/roads/buildings. For accuracy assessment, 80 points were assigned to the 4 classes in a stratified random pattern using Erdas Imagine (Erdas 1997). For the giant reed photographic image near Del Rio, each completed unsupervised classification created 5 data classes. The classes consisted of giant reed, mixed brush, mixed herbaceous vegetation, soil, and water. For accuracy assessment, 100 points were assigned to the 5 classes in a stratified random pattern. For each image, the geographic coordinates of the points were determined and the GPS was used to navigate to the points in ground truthing. Both a producer's and user's accuracy were calculated. The producer's accuracy is the measure of omission error and is the total number of correct points in a category divided by the total number of points of that category as derived from the reference data (ground truthing). The user's accuracy is the measure of commission error and is the total number of correct points in a category divided by the total number of points of that category as derived from the classification data or map data.

An Omnistar (model 3000L) differential GPS and Horita (model GPT-50) real-time GPS video/digital captioner/interphaser was integrated with the video system for the imagery acquired of the Rio Grande on
25 June and 26 July 2002. The GPS acquired the latitude-longitude coordinate data of the aircraft location over the scene of interest, while the video interphaser transferred and superimposed the GPS data at the top of the video scene. The accuracy of the GPS was approximately \pm 20 $\mathrm{m}$ from the center coordinates of each video scene. Giant reed location coordinates were obtained from each video scene and then entered into the computer manually. Before the GPS data were obtained from the video scenes of giant reed, infestation levels were assigned to each image. This was accomplished by breaking down the width of giant reed stands which grow in corridors along the Rio Grande. Infestation levels of giant reed were assigned to each scene using the following criteria: > $120 \mathrm{~m}$ wide, dense; 60 to $120 \mathrm{~m}$ wide, moderate; and $<60 \mathrm{~m}$ wide, light. The length of the corridor was not considered since most were greater than $0.75 \mathrm{~km}$ long. Each video scene of the Rio Grande covered a linear distance of approximately $2100 \mathrm{~m}$.

Personal computer MapInfo-GIS software (MapInfo, Inc. 1998) was used to generate a regional map of the Rio Grande study area in southwest Texas. MapInfo uses StreetWorks which is a street display mapping product that provides coverage of U.S. streets, highways, city and town boundaries, area landmarks, point locations, and water features. StreetWorks is based on U.S. Census Bureau TIGER (Topologically Integrated Geographic Encoding and Referencing) 1995 data that includes street-level detail to the local level. The TIGER map-based system was constructed using USGS 1:100,000 scale digital line graph maps. These maps were produced to geographically map giant reed infestations along the Rio Grande using the airborne video survey GPS data.

Ground truth surveys were conducted at sites where aerial photography and videography were obtained. In some instances, ground surveys were done of some sites prior to acquiring the aerial imagery. Observational data recorded were plant species, cover, and soil type. Low altitude (150-300 m) aerial reconnaissance was also conducted at many sites to verify the presence of giant reed.

\section{Results and Discussion}

Mean light reflectance measurements for giant reed, associated plant species and mixtures of species, and bare soil at 3 wavelengths from 5 sampling dates near Weslaco and South Padre Island are 
Table 1. Mean light reflectance measurements of giant reed and associated plant species in south Texas on 5 dates. Reflectance measurements were made at the visible green, visible red, and near-infrared wavelengths. Measurements were made near Weslaco and South Padre Island, Tex.

\begin{tabular}{|c|c|c|c|c|}
\hline \multirow[b]{2}{*}{ Date } & \multirow[b]{2}{*}{ Plant species } & \multicolumn{3}{|c|}{ Reflectance values ${ }^{1}$ for 3 wavelengths } \\
\hline & & green & red & near-infrared \\
\hline \multirow[t]{6}{*}{ August 2000} & Giant reed & $9.1 \mathrm{~b}$ & $5.0 \mathrm{~b}$ & $39.7 \mathrm{a}$ \\
\hline & Common reed & $9.0 \mathrm{~b}$ & $5.2 \mathrm{~b}$ & $27.4 \mathrm{~b}$ \\
\hline & Honey mesquite & $4.0 \mathrm{~d}$ & $3.6 \mathrm{c}$ & $29.3 \mathrm{~b}$ \\
\hline & Sandbar willow & $5.7 \mathrm{c}$ & $2.4 \mathrm{~d}$ & $28.1 \mathrm{~b}$ \\
\hline & Mixed herbaceous species & $5.7 \mathrm{c}$ & $5.0 \mathrm{~b}$ & $20.7 \mathrm{~d}$ \\
\hline & Bare soil & $13.9 \mathrm{a}$ & $13.3 \mathrm{a}$ & $24.3 \mathrm{c}$ \\
\hline \multirow[t]{8}{*}{ May 2001} & Giant reed & $5.9 \mathrm{~cd}$ & $3.1 \mathrm{~d}$ & 38.1 a \\
\hline & Common reed & $7.6 \mathrm{~b}$ & $4.7 \mathrm{bc}$ & $30.1 \mathrm{~b}$ \\
\hline & Honey mesquite & $4.6 \mathrm{f}$ & $2.9 \mathrm{~d}$ & $30.7 \mathrm{~b}$ \\
\hline & Sandbar willow & 5.1 ef & $2.4 \mathrm{~d}$ & 37.9 a \\
\hline & Sunflower & $5.3 \mathrm{de}$ & $2.9 \mathrm{~d}$ & $40.2 \mathrm{a}$ \\
\hline & Bermudagrass & $6.1 \mathrm{c}$ & $5.1 \mathrm{~b}$ & $26.5 \mathrm{c}$ \\
\hline & Mixed herbaceous species & $6.4 \mathrm{c}$ & $4.3 \mathrm{c}$ & $31.1 \mathrm{~b}$ \\
\hline & Bare soil & $14.2 \mathrm{a}$ & $13.7 \mathrm{a}$ & $25.7 \mathrm{c}$ \\
\hline \multirow[t]{7}{*}{ July 2001} & Giant reed & $9.0 \mathrm{~b}$ & $4.4 \mathrm{c}$ & $48.4 \mathrm{a}$ \\
\hline & Common reed & $9.4 \mathrm{~b}$ & $5.2 \mathrm{~b}$ & $34.6 \mathrm{~b}$ \\
\hline & Honey mesquite & $4.0 \mathrm{e}$ & $2.5 \mathrm{~d}$ & $31.2 \mathrm{~cd}$ \\
\hline & Sandbar willow & $5.1 \mathrm{~d}$ & $2.7 \mathrm{~d}$ & $34.1 \mathrm{bc}$ \\
\hline & Bermudagrass & $6.2 \mathrm{c}$ & $4.7 b c$ & $30.8 \mathrm{~d}$ \\
\hline & Mixed herbaceous species & $5.7 \mathrm{~cd}$ & $4.0 \mathrm{c}$ & $30.5 \mathrm{~d}$ \\
\hline & Bare soil & $13.6 \mathrm{a}$ & $14.4 \mathrm{a}$ & $27.0 \mathrm{e}$ \\
\hline \multirow[t]{7}{*}{ September 2001} & Giant reed & $8.8 \mathrm{~b}$ & $4.3 \mathrm{~b}$ & $49.4 \mathrm{a}$ \\
\hline & Common reed & $7.6 \mathrm{c}$ & $4.0 \mathrm{bc}$ & $30.3 \mathrm{de}$ \\
\hline & Honey mesquite & $4.2 \mathrm{e}$ & $2.4 \mathrm{e}$ & $33.1 \mathrm{~cd}$ \\
\hline & Sandbar willow & $5.9 \mathrm{~d}$ & $3.2 \mathrm{~d}$ & $38.9 \mathrm{~b}$ \\
\hline & Bermudagrass & $6.1 \mathrm{~d}$ & $3.9 \mathrm{bc}$ & $29.1 \mathrm{e}$ \\
\hline & Mixed herbaceous species & $5.9 \mathrm{~d}$ & $3.3 \mathrm{~cd}$ & $34.2 \mathrm{c}$ \\
\hline & Bare soil & $17.7 \mathrm{a}$ & $16.6 \mathrm{a}$ & 30.5 de \\
\hline \multirow[t]{6}{*}{ October 2001} & Giant reed & $9.0 \mathrm{~b}$ & $5.1 \mathrm{~b}$ & $37.5 \mathrm{a}$ \\
\hline & Honey mesquite & $4.3 \mathrm{~d}$ & $2.9 \mathrm{~d}$ & $29.5 c$ \\
\hline & Sandbar willow & $5.5 \mathrm{c}$ & $3.7 \mathrm{c}$ & $34.2 \mathrm{~b}$ \\
\hline & Bermudagrass & $5.4 \mathrm{c}$ & $3.7 \mathrm{c}$ & $25.9 \mathrm{~d}$ \\
\hline & Mixed herbaceous species & $4.4 \mathrm{~d}$ & $2.7 \mathrm{~d}$ & $29.9 \mathrm{c}$ \\
\hline & Bare soil & $15.7 \mathrm{a}$ & $15.0 \mathrm{a}$ & $26.7 \mathrm{~d}$ \\
\hline
\end{tabular}

Talues within a column at each sampling date followed by the same letter do not differ significantly at the 0.05 probability level, according to Duncan's multiple range test.

shown in Table 1. In August 2000, bare soil had higher visible green and red reflectance than the associated plant species. Giant reed and common reed had higher visible green reflectance than the other plant species and mixtures of species, but their reflectance values could not be separated. At the red wavelength, giant reed, common reed, and mixed herbaceous species had similar reflectance values. Giant reed had higher nearinfrared reflectance than the other plant species, mixtures of species, and bare soil.

Differences in visible reflectance among the plant species and mixtures of species was primarily attributed to differences in foliage color and subsequent plant pigments (Myers et al. 1983, Gausman 1985). Foliage colors varied from blue-green for giant reed and common reed, to light color, whereas its moderate near-infrared reflectance was attributed to its primarily sandy-loam surface (Bowers and Hanks 1965, Gerbermann et al. 1987).

In May 2001, giant reed had similar green reflectance to sunflower, bermudagrass, and mixed herbaceous species (Table 1). At the red wavelength, the reflectance value of giant reed could not be distinguished from that of sunflower. The inability to separate the green and red reflectance of giant reed from that of several associated plant species and mixtures in May was attributed to the darker green foliage color of the new spring growth. Giant reed and sunflower had comparable vegetative densities which contributed greatly to their similar near-infrared reflectance values.

For the July 2001 sampling period, giant reed and common reed had higher visible green reflectance than the other plant species and mixtures of species; however, they had similar reflectance values (Table 1). The red reflectance of giant reed was similar to that of bermudagrass and mixed herbaceous species. The near-infrared reflectance of giant reed was higher than that of the other associated species and mixtures of species.

Spectral measurements made in September 2001 showed that giant reed had higher green reflectance than the other associated plant species and mixtures of species (Table 1).

The red reflectance of giant reed did not differ from that of common reed and bermudagrass. At the near-infrared wavelength, giant reed had higher reflectance than the other plant species and mixtures of species.

In October 2001, giant reed had higher green and red reflectance than the other associated plant species and mixtures of species (Table 1). Giant reed also had higher near-infrared reflectance than the other species and mixtures of species.

These findings indicate the best wavelength for differentiating giant reed from associated vegetation is the near-infrared. With the exception of its similarity to common reed, giant reed can also be distinguished at the green wavelength. The optimum times to spectrally distinguish giant reed are during the summer and fall.

Figures $\mathrm{IA}$ and $\mathrm{IC}$ show a positive color-infrared photographic image and a color-infrared digital video image, respectively, obtained 17 August 2001 of a riparian site near Goliad. The photographic image is a portion of a $23 \mathrm{~cm}$ photograph (1:3,000 scale), while the video image (1.0 $\mathrm{m}$ pixel size) was extracted from a larger 


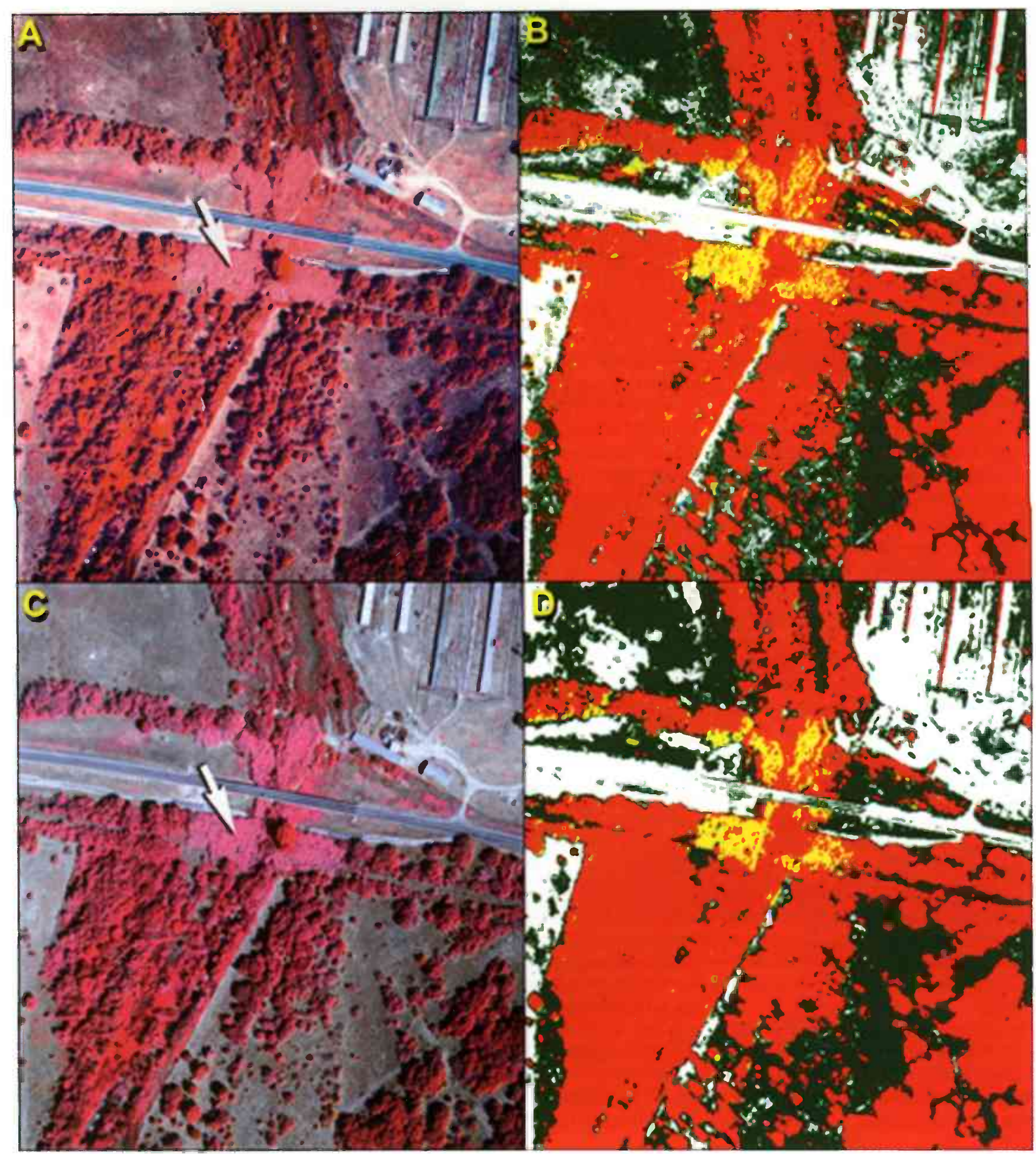

Fig. 1. Color-infrared photographic (A) and videographic (C) images obtained 17 August 2001 of a riparian site near Goliad, Texas, with an infestation of giant reed. The arrows point to the pinkish responses of giant reed. Unsupervised computer classifications of the photographic (B) and video images (D). Color codes for the various land-use types are: yellow = giant reed; red $=$ mixed brush; green $=$ mixed herbaceous vegetation; and white = bare soil, roads, sparsely vegetated areas, and buildings.

video scene. The arrows on the 2 images point to giant reed. In the color-infrared photograph giant reed has a pink image response, mixed brush has various red tones, mixed herbaceous vegetation has a pinkish-gray or gray color, and sparsely vegetated areas, bare soil, roads, and buildings have whitish-gray, blue, or white tones. In the video image giant reed has a pinkish-magenta image response while mixed herbaceous vegetation has a gray color. The video image tonal responses of mixed brush, sparsely vegetated areas, bare soil, roads, and buildings are similar to those in the photograph. The slightly different tonal responses of the video image as compared to the photograph are due to electronic codings of the video image versus chemical emulsion layers of the film.

Figures $1 \mathrm{~B}$ and $1 \mathrm{D}$ show the unsupervised computer classifications of the photographic (Fig. 1A) and video (Fig. 1C) images, respectively, of the riparian site near Goliad. Color codes for the various land-use types in both photographic and video images are: yellow = giant reed; red 
Table 2. An error matrix generated from the classification data and ground data for the 17 August 2001 color-infrared photograph of the riparian study site near Goliad, Tex.

\begin{tabular}{|c|c|c|c|c|c|c|}
\hline \multirow{3}{*}{$\begin{array}{l}\text { Classified } \\
\text { Category }\end{array}$} & \multicolumn{4}{|c|}{ Actual Category } & \multirow[b]{3}{*}{ Total } & \multirow{3}{*}{$\begin{array}{c}\text { User's } \\
\text { Accuracy }\end{array}$} \\
\hline & Mixed & Mixed & Giant & Soil/ & & \\
\hline & Brush & Herbaceous & Reed & Roads' & & \\
\hline Mixed Brush & 20 & 2 & 3 & 0 & 25 & $80.0 \%$ \\
\hline Mixed Herbaceous & 0 & 16 & 1 & 5 & 22 & $72.7 \%$ \\
\hline Giant Reed & 0 & 0 & 14 & 0 & 14 & $100.0 \%$ \\
\hline Soil/Roads' & 0 & 5 & 0 & 14 & 19 & $73.7 \%$ \\
\hline Total & 20 & 23 & 18 & 19 & 80 & \\
\hline Producer's Accuracy & $100.0 \%$ & $69.6 \%$ & $77.8 \%$ & $73.7 \%$ & & \\
\hline
\end{tabular}

Overall accuracy $=80.0 \%$. Kappa $=0.732$.

'Sparsely vegetated areas and buildings were included in this category.

$=$ mixed brush; green $=$ mixed herbaceous vegetation; and white = bare soil, roads, sparsely vegetated areas, and buildings. A qualitative assessment of the 2 classifications showed that the computer did a good job in identifying giant reed and the other land-use types in both images.

Tables 2 and 3 show the error matrices for the color-infrared photographic and video images, respectively, by comparison of the classified data with the ground data for the 80 observations within the riparian study area near Goliad. The overall classification accuracies for the photographic and video images were $80 \%$ and $83.8 \%$, respectively, indicating that $80 \%$ and $83.8 \%$ of the category pixels in each respective image were correctly identified in the classification map.

For the photographic image (Table 2), the producer's accuracy of individual categories ranged from $69.6 \%$ for mixed herbaceous vegetation to $100 \%$ for mixed brush, whereas the user's accuracy ranged from $72.7 \%$ for mixed herbaceous vegetation to $100 \%$ for giant reed. The lower producer's accuracy of giant reed $(83.3 \%)$ was primarily due to its confusion with mixed brush.

The producer's accuracy of individual categories for the video image (Table 3) ranged from $73.9 \%$ for mixed herbaceous vegetation to $100 \%$ for mixed brush, while the user's accuracy ranged from $79 \%$ for soil/roads to $100 \%$ for giant reed. Both the producer's and user's accuracies for giant reed were very good. Like the photographic image classification, errors in the producer's accuracy for giant reed were primarily due to its confusion with mixed brush. However, both the producer's and user's accuracy of giant reed in both the photograph and video images were considered good.

The kappa estimates were 0.732 and 0.783 for the photographic and video image classifications, respectively. This indicated the classifications achieved accuracies that were $73.2 \%$ and $78.3 \%$ better than would be expected from the random assignment of pixels to categories.

Figure $2 \mathrm{~A}$ shows a positive colorinfrared photographic image obtained 25 June 2002 of an area along the Rio Grande near Del Rio infested with giant reed. The photo is a portion of a $23 \mathrm{~cm}$ photograph (1:10,000 scale). The arrow points to the distinct pink image tonal response of giant reed. Mixed brush has a reddish-brown image, mixed herbaceous vegetation has reddish-gray, gray or dark gray tones, soil has a light gray to white color, and water has a black response. The gray diagonal area below the Rio Grande at the bottom of the photograph is Mexico.

The unsupervised computer classification of the color-infrared photograph (Fig. 2A) of the Rio Grande study site is shown in Figure 2B. Color codes for the various land-use types are: yellow = giant reed; red $=$ mixed brush; green $=$ mixed herbaceous vegetation; white $=$ soil; and blue $=$ water. The computer appears to have done a very good job in identifying giant reed.

Table 4 shows an error matrix for the color-infrared photographic image by comparison of the classified data with the ground data for the 100 observations within the Rio Grande study site near Del Rio. The overall classification accuracy was $83.0 \%$, indicating that $83 \%$ of the category pixels in the image were correctly identified in the classification map. The producer's accuracy of individual categories ranged from $72.4 \%$ for soil to $100 \%$ for water, whereas the user's accuracy ranged from $60 \%$ for mixed herbaceous vegetation to $100 \%$ for giant reed, water, and mixed brush. Water was the easiest category to identify. Both the user's and producer's accuracy for giant reed were very good. The errors in the producer's accuracy for giant reed were due to its confusion with mixed herbaceous vegetation. The relative low user's accuracy for mixed herbaceous vegetation was primarily due to its confusion with soil and giant reed. The kappa estimate for this study was 0.780 , indicating the classification achieved an accuracy that is $78 \%$ better than would be expected from the random assignment of pixels to categories.

Table 3. An error matrix generated from the classification data and ground data for the 17 August 2001 color-infrared video image of the riparian study site near Goliad, Tex.

\begin{tabular}{|c|c|c|c|c|c|c|}
\hline \multirow{3}{*}{$\begin{array}{l}\text { Classified } \\
\text { Category }\end{array}$} & \multicolumn{4}{|c|}{ Actual Category } & \multirow[b]{3}{*}{ Total } & \multirow{3}{*}{$\begin{array}{c}\text { User's } \\
\text { Accuracy }\end{array}$} \\
\hline & Mixed & Mixed & Giant & Soil// & & \\
\hline & Brush & Herbaceous & Reed & Roads' & & \\
\hline Mixed Brush & 20 & 2 & 3 & 0 & 25 & $80.0 \%$ \\
\hline Mixed Herbaceous & 0 & 17 & 0 & 4 & 21 & $81.0 \%$ \\
\hline Giant Reed & 0 & 0 & 15 & 0 & 15 & $100.0 \%$ \\
\hline Soil/Roads' & 0 & 4 & 0 & 15 & 19 & $79.0 \%$ \\
\hline Total & 20 & 23 & 18 & 19 & 80 & \\
\hline Producer's Accuracy & $100.0 \%$ & $73.9 \%$ & $83.3 \%$ & $79.0 \%$ & & \\
\hline
\end{tabular}

Overall accuracy $=83.8 \%$. Kappa $=0.783$.

'Sparsely vegetated areas and buildings were included in this category. 


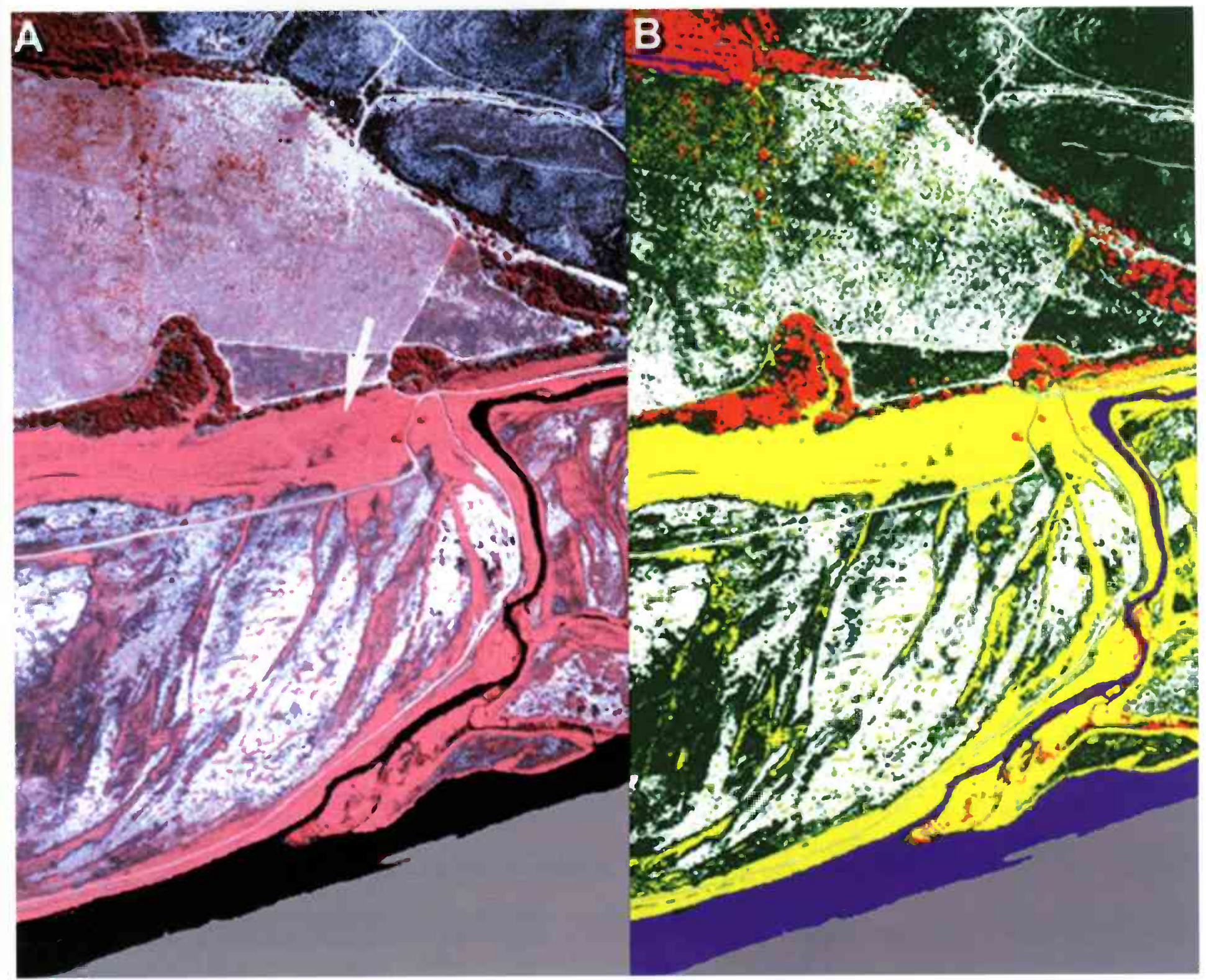

Fig. 2. Color-infrared photographic image (A) obtained on 25 June 2002 of an area along the Rio Grande near Del Rio, Texas, with an infestation of giant reed. The arrow points to the pinkish response of giant reed. Unsupervised classification (B) of the photographic image. Color codes for the various land-use types are: yellow = giant reed; red = mixed brush; green = mixed herbaceous vegetation; white = soil; and blue $=$ water. The gray diagonal area at the bottom on both illustrations is Mexico.

Figure 3A shows a regional GIS map of ary of the map adjacent to Mexico. The an 8-county area of southwest and west Texas. The Rio Grande forms the boundGPS latitude-longitude data provided on the aerial videographic imagery of the Rio
Grande from the June 2002 over flight have been integrated with the GIS to georeference infestations of giant reed along

Table 4. An error matrix generated from the classification data and ground data for the 25 June 2002 color-infrared photograph of the Rio Grande study site near Del Rio, Tex.

\begin{tabular}{|c|c|c|c|c|c|c|c|}
\hline \multirow{3}{*}{$\begin{array}{l}\text { Classified } \\
\text { Category }\end{array}$} & \multicolumn{5}{|c|}{ Actual Category } & \multirow{3}{*}{ Total } & \multirow{3}{*}{$\begin{array}{c}\text { User's } \\
\text { Accuracy }\end{array}$} \\
\hline & Giant & Water & Mixed & Soil & Mixed & & \\
\hline & Reed & & Brush & & Herbaceous & & \\
\hline$\overline{\text { Giant Reed }}$ & 20 & 0 & 0 & 0 & 0 & 20 & $100.0 \%$ \\
\hline Water & 0 & 11 & 0 & 0 & 0 & 11 & $100.0 \%$ \\
\hline Mixed Brush & 0 & 0 & 10 & 0 & 0 & 10 & $100.0 \%$ \\
\hline Soil & 0 & 0 & 0 & 21 & 3 & 24 & $87.5 \%$ \\
\hline Mixed Herbaceous & 5 & 0 & 1 & 8 & 21 & 35 & $60,0 \%$ \\
\hline$\overline{\text { Total }}$ & 25 & 11 & 11 & 29 & 24 & 100 & \\
\hline Producer's Accuracy & $80.0 \%$ & $100.0 \%$ & $90.9 \%$ & $72.4 \%$ & $87.5 \%$ & & \\
\hline
\end{tabular}

Overall accuracy $=83.0 \%$. Kappa $=0.780$. 
$\mathbf{A}$

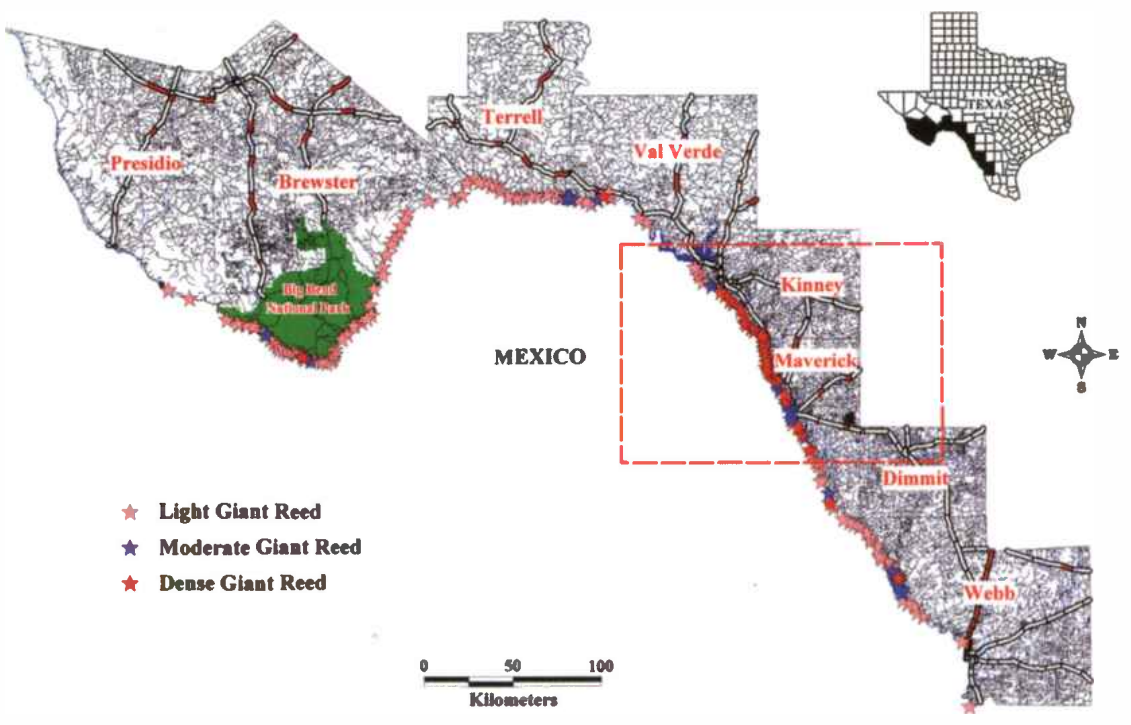

B

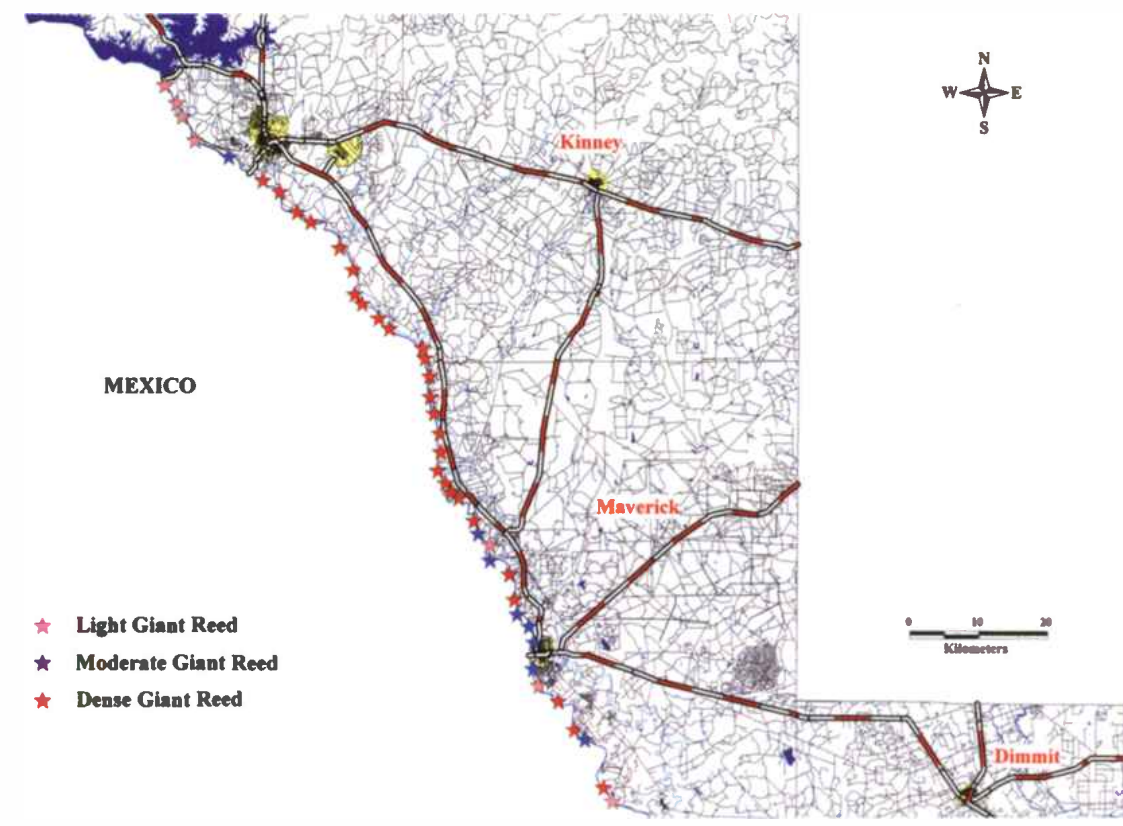

Fig. 3. Regional GIS map (A) of an 8-county area along the Rio Grande in southwest and west Texas. The Rio Grande forms the western boundary of the map with Mexico. The symbols along the Rio Grande represent GPS latitude-longitude coordinates of giant reed infestations obtained from airborne video imagery. A detailed GIS map (B) of a portion of the Rio Grande with several dense infestations of giant reed

the river. Areas with red stars represent the densest populations of giant reed, those with blue stars have moderate populations, and those represented by pink stars have light populations. Approximately 600 river-km of the Rio Grande area surveyed was infested with giant reed. The densest populations of giant reed are located in Kinney and Maverick counties in southwest Texas. Due to the small scale of the map, many of the symbols are stacked on scenes. Ground surveys confirmed the presence of giant reed at all the plotted locations on the map. Small stands or individual plants of common reed were found growing in association with giant reed at several scattered locations. However, very little common reed could be distinguished in the imagery. Where it could be differentiated, common reed generally had a red- dish-pink image response as compared to the pink image tone of giant reed.

Figure 3B shows a more detailed GIS map of the portion of the Rio Grande with the densest infestations of giant reed in Kinney and Maverick counties and corresponds to the enclosed box in Figure 3A. This map more clearly depicts the infested areas and allows one to associate the general land-use characteristics (i.e., highways, roads) with the GPS locations where giant reed occurred.

\section{Conclusions}

These findings indicate that giant reed had higher near-infrared light reflectance than associated plant species in summer and fall and that color-infrared aerial photography and videography can be used successfully for distinguishing infestations of this invasive weed. Ground reflectance data support these findings. Computer image analysis of color-infrared photographic and videographic images showed that giant reed infestations can be quantified. Accuracy assessments performed on classified maps showed that giant reed had user's and producer's accuracies that ranged from $78 \%$ to $100 \%$. Airborne videography was integrated with GPS and GIS technologies to map giant reed infestations along a stretch of the Rio Grande in southwest and west Texas. The integration of these technologies are valuable and cost-effective tools that can enable natural resource managers to develop regional maps depicting where giant reed infestations occur over often large and inaccessible areas. The GIS technology can be used to combine weed distribution maps with other existing data (map features or digital elevation data) and create new information (watershed basin, streams, slope, and aspect maps) for a more in depth assessment of giant reed population distribution (Anderson et al. 1996). The joint use of these technologies provides previously unavailable information about the extent and spatial dynamics of giant reed along the Rio Grande.

\section{Literature Cited}


Anderson, G. L., J. H. Everitt, D. E. Escobar, N. R. Spencer, and R. J. Andrascik. 1996. Mapping leafy spurge (Euphorbia esula) infestations using aerial photography and geographic information systems. Geocarto Int. I 1(1):81-89.

Bell, G. P. 1997. Ecology and management of Arundo donax and approaches to riparian habitat restoration in southern California. pp. 103-113. In: J. H. Brock, M. Wade, P. Pysek, and D. Green, (eds.) Plant Invasion Studies from North America and Europe. Blackhuys Publishers, Leiden, The Netherlands.

Bowers, S. A. and R. J. Hanks. 1965. Reflectance of radiant energy from soils. Soil Sci. 100:130-138.

Cheatham, S. and M. C. Johnston. 1995. The useful wild plants of Texas, the southeastern and southwestern United States, the Southern Plains, and northern Mexico. Useful Wild Plants, Inc., Austin, Tex. Volume 1, 581 p.

Dewey, S. A., K. P. Price, and D. Ramsey. 1991. Satellite remote sensing of Dyer's woad (Isatis tinctoria). Weed Tech. 5:479-484.

Dipietro, D., S. L. Ustin, and E. Underwood. 2002. Mapping the invasive plant Arundo donax at Camp Pendleton Marine Base using AVIRIS. Proc. 10th JPL Airborne Visible Infrared Imaging Spectrometer (AVIRIS) Workshop. Jet Propulsion Lab., Pasadena, Calif. CD-ROM.

Driscoll, R. S., J. H. Everitt, R. Haas, and P. T. Tueller. 1997. Ranges and range management. pp. 44I-474. In: W. R. Philipson (ed.) Manual of Photographic Interpretation. Amer. Soc. Photogrammetry and Remote Sensing, Bethesda, Md.

Dudley, T. L. 2000. Arundo donax. pp. 53-58. In: C. C. Bossard, J. M. Randal, and M. C. Hosovsky (eds.). Invasive Plants of California Wildlands, Univ. of California Press, Berkeley, Calif.

Dudley, T. L. and B. Collins. 1995. Biological invasions in California wetlands: the impacts and control of non-indigenous species in natural areas. Pacific Institute for Studies in Development, Environment, and Security. Oakland, Calif. 62 p.

Erdas, Inc. 1997. Erdas-Imagine v8.3 tour guide. Erdas, Inc. Atlanta, $\mathrm{Ga}$.

Everitt, J. H., R. D. Pettit, and M. A. Alaniz. 1987. Remote sensing of broom snakeweed (Gutierrezia sarothrae) and spiny aster (Aster spinosus). Weed Sci. 295-302.

Everitt, J. H., A. J. Richardson, and P. R. Nixon. 1986. Canopy reflectance characteristics of succulent and nonsucculent rangeland plant species. Photogramm. Eng. and Remote Sensing 52:1891-1897.

Everitt, J. H., M. A. Alaniz, D. E. Escobar, and M. R. Davis. 1992. Using remote sensing to distinguish common (Isocoma coronopifolia) and Drummond goldenweed (Isocoma drummondii). Weed Sci. 40:621-628.

Everitt, J. H.., D. E. Escobar, I. Cavazos, J. R. Noriega, and M. R. Davis. 1995. A three-camera multispectral digital video imaging system. Remote Sensing Environ. 54:333-337.
Everitt, J. H., D. E. Escobar, M. A. Alaniz, M. R. Davis, and J. V. Richerson. 1996. Using spatial information technologies to map Chinese tamarisk (Tamarix chinensis) infestations. Weed Sci. 44:194-201.

Everitt, J. H., J. V. Richerson, M. A. Alaniz, D. E. Escobar, R. Villarreal, and M. R. Davis. 1994. Light reflectance characteristics and remote sensing of Big Bend loco (Astragalus mollissimus var. earlei) and Wooton loco (Astragalus wootonii). Weed Sci. 42:115-122.

Frandsen, P. and N. Jackson. 1994. The impact of Arundo donax on flood plain control and endangered species. pp. 13-16. In: N. E. Jackson, P. Frandsen, and S. Duthoit (Compilers) Arundo donax Workshop Proceedings. California Exotic Pest Plant Council, Riverside.

Gausman, H. W. 1985. Plant leaf optical parameters in visible and near-infrared light. Graduate Studies Texas Tech University, No. 29. Texas Tech Press. Lubbock, Tex. 78 p.

Gausman, H. W., J. H. Everitt, A. H. Gerbermann, and R. L. Bowen. 1977a. Canopy reflectance and film image relations among three south Texas rangeland plants. J. Range Manage. 30:449-450.

Gausman, H. W., R. M. Menges, D. E. Escobar, J. H. Everitt, and R. L. Bowen. 1977b. Pubescence affects spectra and imagery of silverleaf sunflower (Helianthus argophyllus). Weed Sci. 25:437-440.

Gerbermann, A. H., C. L. Wiegand, A. J. Richardson, and R. R. Rodriguez. 1987. Diurnal soil reflectance in the 450 - to 2450 $\mathrm{nm}$ interval as related to photographic and video sensing. Proc. $11^{\text {th }}$ Biennial Workshop Color Aerial Photography and Videography in the Plant Sciences. Amer. Soc. Photogramm. and Remote Sensing, Bethesda, Md. pp. 184-195.

Lass, L. W. and R. H. Callihan. 1997. The effect of phenological stage on detectability of yellow hawkweed (Heiracium pratense) and oxeye daisy (Chrysanthemum leucanthemum) with remote multispectral digital imagery. Weed Tech. 11:248-256.

Lass, L. W., H. W. Carson, and R. H. Callihan. 1996. Detection of yellow starthistle (Centaurea solstitialis) and common St. Johnswort (Hypericum perforatum) with multispectral digital imagery. Weed Tech. 10:466-474.

MapInfo, Inc. 1998. MapInfo Professional V5.0. MapInfo Inc. Troy, N. Y.

Myers, V. I., M. E. Bauer, H. W. Gausman, W. G. Hart, J. L. Heilman, R. B. McDonald, A. B. Park, R. A. Ryerson, T. J. Schmugge, and F. C. Westin. 1983. Remote sensing in agriculture. In: R. N. Colwell, (ed.) Manual of Remote Sensing. Amer. Soc. Photogramm., Falls Church, Virg. pp. 2111-2228.

Parker-Williams, A. and E. R. Hunt, Jr. 2002. Estimation of leafy spurge cover from hyperspectral imagery using mixture tuned matched filtering. Remote Sens. Environ. $82: 446-456$
Perdue, R. E., Jr. 1958. Arundo donax - A source of musical reeds and industrial cellulose. Econ. Bota. 12:368-404.

Richardson, A. J. 1981. Measurement of reflectance factors under daily and intermittent irradiance variations. Appl. Optics 20:1336-1340

Richardson, A. J., D. E. Escobar, H. W. Gausman, and J. H. Everitt. 1981. Use of Landsat-2 data technique to estimate silverleaf sunflower infestation. Proc. Machine Processing of Remotely Sensed Data Sympos. Purdue University, West Lafayette, Ind. pp. 676-683.

Robinson, B. F., M. E. Bauer, D. P. DeWitt, L. F. Silva, and V. C. Vanderbilt. 1979. Multiband radiometer for field use. Measurements of Optical Radiations, SPIE Vol. 196. SPIE, Bellingham, Wash. pp. 8-15.

Steel, R. G. D. and J. H. Torrie. 1980. Principles and procedures of statistics. McGraw-Hill, New York, N. Y. 481 p.

Tracy, J. L. and C. J. Deloach. 1998. Suitability of classical biological control of giant reed (Arundo donax) in the United States. pp. 73-109. In: C. E. Bell (ed.) Proc. Arundo and Saltcedar Workshop. University of California Cooperative Extension Service, Holtville, Calif.

Tueller, P. T. 1982. Remote sensing for range management. pp. 125-140. In: C. J. Johannsen and J. L. Sanders (eds.) Remote Sensing for Resource Management. Soil Conserv. Soc. Amer., Ankeny, lowa.

Tueller, P. T., 1989. Remote sensing technology for rangeland management applications. J. Range Manage. 42:442-453. 